\title{
An Ethnobotanical Study of Medicinal Plants in Amaro Woreda, Ethiopia
}

\author{
Fisseha Mesfin, Talemos Seta, and Abreham Assefa
}

\section{Research}

\begin{abstract}
An ethnobotanical study was conducted in Amaro Woreda, Southern Nations, Nationalities, and People's Region (SNNPR), Ethiopia, with an objective to (1) document indigenous knowledge of the people on the use of medicinal plants and (2) investigate plant species that are used as medicines for the treatment of human health problems, thereby identifying indigenous knowledge for the conservation of biological and cultural diversities and threatening factors on plant species. Plant and ethnobotanical information were collected from selected areas of the woreda. A total of 17 traditional healers, most of them aged from 28 to 70 years were selected, and information was collected through questionnaires and personal interviews during field trips in the Korre ethnic group from August to December 2012. Descriptive analysis was performed for the data collected. A total of 56 medicinal plant species were reported by traditional healers of the Korre ethnic group, representing 52 genera and 31 families. The majority of plants recorded $(77 \%)$ were wild. Of the plants, $38 \%$ were herbs and $34 \%$ shrubs. Thirty-one human ailments were identified by the traditional healers of the study area. Leaves constituted $33 \%$ of the total uses followed by roots $(27 \%)$. Fifty-seven percent of the healer remedies were applied orally while $23 \%$ were applied on the skin. The plants recorded from Korre group were the ones with the highest fidelity level (FL) values. Conservation priority should be given for identified threatened medicinal plants, promoting in situ and ex situ conservation.
\end{abstract}

\section{Introduction}

Medicinal plants form the basis of traditional healthcare systems for the majority of the population of developing nations. About 500 million people in south Asian countries alone are reported to seek health security from plants
(Abebe 2001). Demand has been increasing as a result of growth of human population and the frequently inadequate provision of modern medicine (Marshall 1998).

In Ethiopia, there is a long history of using medicinal plants to treat a variety of ailments (Kibebew 2001). Eighty percent of the human population and $90 \%$ of livestock in Ethiopia rely on traditional medicine, as most plants species have shown very effective medicinal value for some ailments of human beings and domestic animals (Abebe 2001). The major reasons why medicinal plants are demanded in Ethiopia are due to culturally linked traditions, the trust the communities have in traditional medicine, and relatively low cost in using them (Bekele 2007). Ethiopia is believed to be home for about 6500 species of higher plants, with approximately $12 \%$ of these endemic (UNEP 1995). The greater concentration of medicinal plants are found in the south and southwestern parts of the country following the concentration of biological and cultural diversity (Belayneh et al. 2012). Citations made from written records (Bekele 2007) of medicinal plants in

\section{Correspondence}

Fisseha Mesfin, Talemos Seta, and Abreham Assefa, Department of Biology, Dilla University, ETHIOPIA. talemos.seta@yahoo.com

Ethnobotany Research \& Applications 12:341-354 (2014)

Published: 05 September 2014 
central, north, and northwestern part of Ethiopia are thus only small fractions of medicinal plants in Ethiopia. The distribution of knowledge and services of medicinal plants are hierarchically structured. Services are obtained from the family, neighborhood and village, or beyond.

The issue of medicinal plant conservation in Ethiopia today calls for study and documentation before the accelerated ecological and cultural transformation distort the physical entities and the associated knowledge base (Bekele 2007). Derogatory attitudes towards practitioners of traditional medicine have forced healers to keep their knowledge and practices to themselves (Zerabruk \& Yirga 2012). Moreover, the indigenous knowledge associated with the conservation and use of medicinal plants is also disappearing at an alarming rate (Regassa 2013). In this context, the present study was conducted with the major objective of documenting the ethnomedicinal plant species used to treat human health problems and the associated indigenous knowledge.

The Korre ethnic group in Amaro Woreda, Southern Nations, Nationalities, and People's Region (SNNPR), Ethiopia was selected for study. The study concentrated on (1) identifying the plant species and parts used in ethnomedicine and, (2) documenting indigenous knowledge of the use of medicinal plants and understandings of conservation of biological and cultural diversities as well as threat factors encountered by those plants in the study area.

\section{Materials and Methods}

\section{Description of study area}

Amaro was considered as a "special" woreda in SNNPR, Ethiopia. Since then, it has become a woreda in the newly established Segen Area People's Zone in SNNPR. It is located in the Great Rift Valley and is bordered on the south by Burji Special Woreda, on the east by Gamo Gofa and Lake Chamo, and on the north and east by the Oromia Region (Figure 1). It is divided into 32 kebeles. The administrative center of the woreda is Kele. The highest peak in the woreda is Mount Delo $(3240 \mathrm{~m})$, which is part of the Amaro Mountains. Most of the western part of this woreda lies inside the Nechisar National Park, which is located in Gamo Gofa zone of SNNPR.

Amaro Woreda has a population of 139,727 , of which 70,018 are men and 69,709 are women; $4 \%$ of its population are urban dwellers (CSA 2005). With an area of 1534 $\mathrm{km}^{2}$, Amaro has a population density of 91 people per $\mathrm{km}^{2}$. The largest ethnic group living in Amaro is the Korre $(93 \%)$. Koorete is spoken as the first language by $98 \%$ of the inhabitants, $<1 \%$ spoke Oromiffa, and $<1 \%$ spoke Amharic. About $52 \%$ of the population said they were Protestants, $35 \%$ practiced traditional religions, and $10 \%$ practiced Ethiopian Orthodox Christianity.

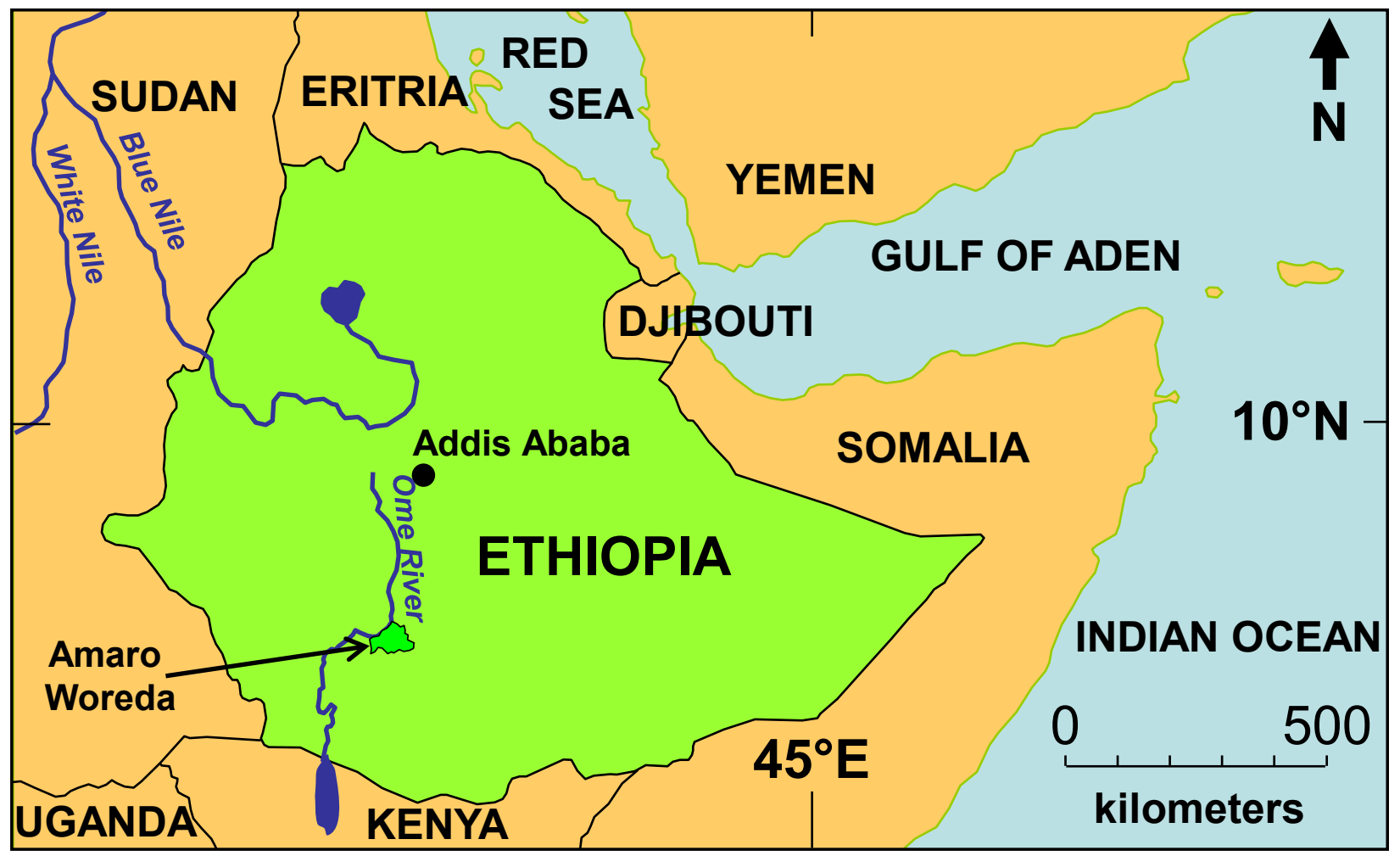

Figure 1. Amaro Woreda in Ethiopia. 


\section{Mesfin et al. - An Ethnobotanical Study of Medicinal Plants in Amaro Woreda, 343 Ethiopia}

\section{Health problems and health institutions}

Predominant health problems in Amaro are communicable diseases such as malaria, diarrhea, tuberculosis, malnutrition, and gastritis among others. Children and women are the most common victims of diseases associated with malnutrition as a result of poor diet. At present, there are 7 clinics, 9 functional health posts, and one health center in Amaro. These institutions are poorly equipped with medical and other basic facilities. The drug supply is constrained by severe budget limitations. The woreda health service coverage in general is not satisfactory. The numbers of different levels of health institutions do not fulfill the national standard. Based on the new national standard and the information from Amaro Woreda Health Desk, seven more health centers and 33 health posts are needed to accommodate the size of the population.

\section{Data collection}

Traditional medical practitioners (TMPs) were the main informants in the survey. They were identified with the help of the traditional ruler and some of the elders of the tribe. A total of 17 TMPs were interviewed, amongst whom five were literate. Their ages range from 28 to 70 years with more of them on the older side of the range. Most of the informants were men as there were only four females. After seeking their consent, the TMPs were interviewed using semi-structured questionnaires and open-ended conversations. Trips were made to the sites where TMPs normally go to harvest plants, and during such trips there were discussions with the TMPs in addition to the interviews.

The interviews and discussions were carried out through a translator. Data on the local names of the plants, the plant parts used, diseases treated, mode of usage, and administration were collected in the field from August to December 2012. Plants recorded were mentioned by at least two TMPs as treating the same disease in order to confirm its use. Fertile specimens of the plants were collected in the field using standard methods (Martin 1995) together with the TMPs. The collected specimens were identified by consulting floristic literature (Edwards et al. 1997, 2000, 1995, Hedberg \& Edwards 1989, 1995, Hedberg et al. 2003, 2004) and cross-checking with identified collections at the National Herbarium in Addis Ababa University, Ethiopia.

\section{Data analysis}

The data obtained from the field and collected from the informants were organized and analyzed. Fidelity level (FL) value was calculated for each medicinal plant reported to be used against human ailments to estimate its relative healing potential using the formula $\mathrm{FL}(\%)=I p / l u \times 100$, where $I p$ is the number of informants who independently indicated the use of a species for the same major ailment and $I u$ the total number of informants who mentioned the plant for any major ailment (Alexiades \& Sheldon 1996). Prior to the calculation of FL, all human ailments mentioned during interviews were grouped into major disease categories, using a similar approach employed elsewhere (Heinrich et al. 1998). It is assumed that plants which are used in some repetitive fashion for the same purpose are more likely to be biologically active.

\section{Results}

\section{Diversity of medicinal plant species}

Fifty-six plant species were reported by TMP's of the Korre community for their medicinal uses, representing 52 genera and 31 plant families. Among them a majority of the plants $(77 \%)$ were wild, $19 \%$ were cultivated, and $4 \%$ were indicated as both cultivated and wild. Among these plants, 21 were herbs, 19 shrubs, 13 trees, and 3 were climbers (Figure 2). The family with highest number of utilized medicinal plants in the area was Solanaceae (6 species), followed by Euphorbiaceae (5) and Fabaceae and Lamiaceae (4 each) (Table 1).

The study of plant abundance data revealed that $28(50 \%)$ were presently safe, $18(32.1 \%)$ sporadic, $7(12.5 \%)$ threatened, and status of $3(5.3 \%)$ plants was not known.

\section{Ailments treated, plant parts used, and modes of remedy preparations}

Thirty-one human diseases/ailments were identified by the traditional healers of the study area (Table 1). The greatest number of plants were used to treat of malaria (9 plants) followed by snake bite (7 plants); internal worms and hemorrhoids (kintarot) (6 plants each); cough, mich (febrile disease characterized by fever, headache, sweating, herpes labialis, and muscle spasm (Teklehaymanot

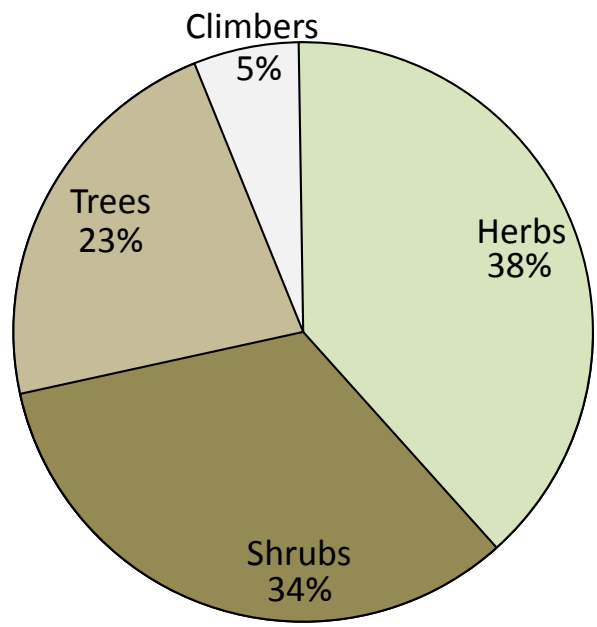

Figure 2. Habit of plant species used by Korre ethnic group, Amaro Woreda, SNNPR, Ethiopia. 
Table 1. Medicinal plants with mode of preparation used by local people from Amaro Woreda, SNNPR, Ethiopia. Habit: Tree (T), Herb (H), Shrub (S), Climber (C). Local names: Amharic (A), Oromiffa (O); all other names are Koorete.

\begin{tabular}{|c|c|c|c|c|}
\hline Scientific name & Local name & Habit & Uses & Mode of Preparation \\
\hline $\begin{array}{l}\text { Acacia nilotica (L.) Delile } \\
\text { Fabaceae }\end{array}$ & Gwemoriya & $\bar{T}$ & $\begin{array}{l}\text { Yeferes ekeke } \\
\text { (lymphangitis) }\end{array}$ & $\begin{array}{l}\text { The powder of leaf and root mixed with water } \\
\text { is applied as paste. }\end{array}$ \\
\hline \multirow{2}{*}{$\begin{array}{l}\text { Acacia seyal Delile } \\
\text { Fabaceae }\end{array}$} & \multirow[t]{2}{*}{ Tundukiyac } & \multirow[t]{2}{*}{$\mathrm{T}$} & Epilepsy & Bark burned smoke is inhaled. \\
\hline & & & Malaria & Gum from bark is chewed. \\
\hline \multirow[t]{3}{*}{$\begin{array}{l}\text { Achyranthes aspera L. } \\
\text { Amaranthaceae }\end{array}$} & \multirow[t]{3}{*}{ Begegechoo } & \multirow[t]{3}{*}{ C } & Blood clotting & $\begin{array}{l}\text { Dried leaves are powdered and mixed with } \\
\text { water and taken orally. }\end{array}$ \\
\hline & & & Snake bite & $\begin{array}{l}\text { Root juice is mixed with milk and drunk for } \\
3 \text { days. }\end{array}$ \\
\hline & & & Gonorrhea & $\begin{array}{l}\text { Combination of green fruit and stem with } \\
\text { butter is drunk for } 7 \text { days. }\end{array}$ \\
\hline \multirow{2}{*}{$\begin{array}{l}\text { Acokanthera schimperi } \\
\text { (A.DC.) Schweinf. } \\
\text { Apocynaceae }\end{array}$} & \multirow[t]{2}{*}{ Qaraaruu } & \multirow[t]{2}{*}{$\mathrm{T}$} & Ekeke & $\begin{array}{l}\text { Fresh crushed leaves mixed with butter is } \\
\text { applied as paste. }\end{array}$ \\
\hline & & & Skin disease & $\begin{array}{l}\text { Juice of fresh leaves is mixed with coconut } \\
\text { milk and the mixture is applied topically on } \\
\text { skin. }\end{array}$ \\
\hline $\begin{array}{l}\text { Ajuga integrifolia } \\
\text { Buch.-Ham. } \\
\text { Lamiaceae }\end{array}$ & Anamuro $(A)$ & $\mathrm{H}$ & Anthrax & $\begin{array}{l}\text { Root is powdered with atella and drunk. Also, } \\
\text { fresh leaves mixed with grasses are eaten. }\end{array}$ \\
\hline \multirow{3}{*}{$\begin{array}{l}\text { Albizia amara (Roxb.) } \\
\text { B.Boivin } \\
\text { Fabaceae }\end{array}$} & \multirow[t]{3}{*}{ Ondoddee } & \multirow[t]{3}{*}{$\bar{T}$} & Mich & Infusion of the roots is inhaled. \\
\hline & & & Cough & $\begin{array}{l}\text { Fresh leaves are crushed and drunk with } \\
\text { coffee. }\end{array}$ \\
\hline & & & Malaria & Bark is chewed. \\
\hline $\begin{array}{l}\text { Albuca abyssinica Jacq. } \\
\text { Hyacinthaceae }\end{array}$ & Qorsa bofa & $\mathrm{H}$ & Snake bite & $\begin{array}{l}\text { The exudates are mixed with melted butter } \\
\text { and drunk for } 5 \text { days. }\end{array}$ \\
\hline \multirow{2}{*}{$\begin{array}{l}\text { Allium sativum } \mathrm{L} \text {. } \\
\text { Amaryllidaceae }\end{array}$} & \multirow{2}{*}{$\begin{array}{l}\text { Nechshinkurte } \\
\text { (A) }\end{array}$} & \multirow[t]{2}{*}{$\mathrm{H}$} & Influenza & Bulbs (5-10) are taken orally. \\
\hline & & & $\begin{array}{l}\text { Headache, } \\
\text { chest pain, } \\
\text { malaria, } \\
\text { stomach ache }\end{array}$ & $\begin{array}{l}\text { Bulbs }(3-7) \text { are chewed and swallowed for } \\
\text { treatment. }\end{array}$ \\
\hline \multirow[t]{2}{*}{$\begin{array}{l}\text { Aloe pirottae A.Berger } \\
\text { Xanthorrhoeaceae }\end{array}$} & \multirow[t]{2}{*}{ Hargeesa } & \multirow[t]{2}{*}{$S$} & Snake bite & $\begin{array}{l}\text { Crushed, powdered, and mixed with honey } \\
\text { and applied as paste. }\end{array}$ \\
\hline & & & Hemorrhoid & $\begin{array}{l}\text { Powder obtained from the shade-dried } \\
\text { leaves is mixed with coconut oil and applied } \\
\text { topically on the cut edge. }\end{array}$ \\
\hline \multirow[t]{3}{*}{$\begin{array}{l}\text { Amaranthus caudatus } \mathrm{L} \text {. } \\
\text { Amaranthaceae }\end{array}$} & \multirow[t]{3}{*}{ Chale-Shullo } & \multirow[t]{3}{*}{$\mathrm{H}$} & \begin{tabular}{|l|} 
Amoebic \\
dysentery
\end{tabular} & $\begin{array}{l}\text { Concoction of seed mixed with water and } \\
\text { sugar is taken. }\end{array}$ \\
\hline & & & $\begin{array}{l}\text { Intestinal } \\
\text { parasites }\end{array}$ & $\begin{array}{l}\text { Root bark, flower, and fruit are powdered } \\
\text { together and mixed with coffee and drunk } \\
\text { early in the morning before breakfast. } \\
\end{array}$ \\
\hline & & & Ascaris & Seeds are eaten to remove ascaris. \\
\hline \multirow{2}{*}{$\begin{array}{l}\text { Artemisia afra Jacq. } \\
\text { ex Willd. } \\
\text { Asteraceae }\end{array}$} & \multirow[t]{2}{*}{ Aemechoae } & \multirow[t]{2}{*}{$\mathrm{H}$} & Evil eye & Dried leaves burnt for smoke \\
\hline & & & Mich & $\begin{array}{l}\text { Fresh leaves are crushed mixed with water } \\
\text { and applied on affected part of skins. }\end{array}$ \\
\hline \multirow{2}{*}{$\begin{array}{l}\text { Arundinaria alpina } \\
\text { K.Schum. } \\
\text { Poaceae }\end{array}$} & \multirow[t]{2}{*}{ Kerkeha $(\mathrm{A})$} & \multirow[t]{2}{*}{$\mathrm{H}$} & Snake bite & $\begin{array}{l}\text { Dressing of crushed fresh root is applied to } \\
\text { bite. }\end{array}$ \\
\hline & & & $\begin{array}{l}\text { Chiffea } \\
\text { (Eczema) }\end{array}$ & $\begin{array}{l}\text { Powdered and mixed with honey and drunk } \\
\text { for } 3 \text { days at morning. }\end{array}$ \\
\hline
\end{tabular}


Mesfin et al. - An Ethnobotanical Study of Medicinal Plants in Amaro Woreda, 345 Ethiopia

\begin{tabular}{|c|c|c|c|c|}
\hline Scientific name & Local name & Habit & Uses & Mode of Preparation \\
\hline $\begin{array}{l}\text { Asparagus } \\
\text { africanus Lam. } \\
\text { Asparagaceae }\end{array}$ & unknown & C & $\begin{array}{l}\text { Sexual } \\
\text { impotency }\end{array}$ & $\begin{array}{l}\text { Leaf powder is mixed with butter and drunk } \\
\text { for } 3 \text { days before sexual intercourse. }\end{array}$ \\
\hline $\begin{array}{l}\text { Becium filamentosum } \\
\text { (Forssk.) Chiov. } \\
\text { Lamiaceae }\end{array}$ & unknown & $\mathrm{H}$ & Black leg & $\begin{array}{l}\text { Crushed fresh leaves are eaten with a } \\
\text { mixture of attela. }\end{array}$ \\
\hline \multirow[t]{2}{*}{$\begin{array}{l}\text { Capsicum annuum L. } \\
\text { Solanaceae }\end{array}$} & \multirow[t]{2}{*}{ Mixxamixxoae } & \multirow[t]{2}{*}{$\mathrm{H}$} & $\begin{array}{l}\text { Sexual } \\
\text { impotence }\end{array}$ & Fruit are eaten. \\
\hline & & & Internal worms & $\begin{array}{l}\text { Dried leaves are ground into powder and } \\
\text { mixed with table salt in addition to water and } \\
\text { drunk for treatment. }\end{array}$ \\
\hline $\begin{array}{l}\text { Carissa spinarum L. } \\
\text { Apocynaceae }\end{array}$ & $\operatorname{Agam}(\mathrm{A})$ & $S$ & Gonorrhea & $\begin{array}{l}\text { Dried stem bark powder and fresh root } \\
\text { decoction are mixed with honey and drunk. }\end{array}$ \\
\hline $\begin{array}{l}\text { Catha edulis (Vahl) Endl. } \\
\text { Celastraceae }\end{array}$ & Chatyae & $S$ & Hypertension & Fresh leaves are chewed. \\
\hline \multirow{3}{*}{$\begin{array}{l}\text { Citrus aurantiifolia } \\
\text { (Christm.) Swingle } \\
\text { Rutaceae }\end{array}$} & \multirow[t]{3}{*}{ Tutto } & \multirow[t]{3}{*}{$S$} & Hypertension & Fruit and fruit juice are taken. \\
\hline & & & Skin cutting & Fruit is squeezed on the cut body part. \\
\hline & & & Cough & $\begin{array}{l}\text { Juice of the fruit with few drops of pure honey } \\
\text { is administered orally. }\end{array}$ \\
\hline $\begin{array}{l}\text { Combretum molle R.Br. } \\
\text { ex G.Don } \\
\text { Combretaceae }\end{array}$ & Agalo $(A)$ & $T$ & Malaria & $\begin{array}{l}\text { Leaf and bark powder are mixed with tea or } \\
\text { coffee and drunk. }\end{array}$ \\
\hline $\begin{array}{l}\text { Commelina } \\
\text { benghalensis L. } \\
\text { Commelinaceae }\end{array}$ & Lalunxxae $(\mathrm{O})$ & $\mathrm{H}$ & $\begin{array}{l}\text { Internal } \\
\text { worms, tape } \\
\text { worm }\end{array}$ & $\begin{array}{l}\text { Leaf powder is mixed with skimmed milk and } \\
\text { drunk in the morning for } 3 \text { days. }\end{array}$ \\
\hline \multirow{3}{*}{$\begin{array}{l}\text { Commiphora africana } \\
\text { (A.Rich.) Endl. } \\
\text { Burseraceae }\end{array}$} & \multirow[t]{3}{*}{ unknown } & \multirow[t]{3}{*}{$S$} & Malaria & $\begin{array}{l}\text { The root and resin are boiled in water and } \\
\text { taken for } 7 \text { days. }\end{array}$ \\
\hline & & & $\begin{array}{l}\text { Chiffea/skin } \\
\text { irritation }\end{array}$ & $\begin{array}{l}\text { Powder obtained from shade-dried leaves is } \\
\text { mixed with coconut oil and applied topically } \\
\text { on the area of irritation. }\end{array}$ \\
\hline & & & Scabies & $\begin{array}{l}\text { Leaf is crushed, enclosed in cotton, and } \\
\text { placed on the scabies. The juice is also } \\
\text { swallowed. }\end{array}$ \\
\hline \multirow[t]{3}{*}{$\begin{array}{l}\text { Cordia africana Lam. } \\
\text { Boraginaceae }\end{array}$} & \multirow[t]{3}{*}{ Wanza (A) } & \multirow[t]{3}{*}{$\mathrm{T}$} & Malaria & $\begin{array}{l}\text { Decoction of roots and inner bark with ginger } \\
\text { is consumed. }\end{array}$ \\
\hline & & & Diarrhea & Fruit (5-7) are eaten daily in the morning. \\
\hline & & & $\begin{array}{l}\text { Dental } \\
\text { problem }\end{array}$ & $\begin{array}{l}\text { Dried bark is powdered and used as tooth } \\
\text { powder to get relief from dental problems. }\end{array}$ \\
\hline \multirow{5}{*}{$\begin{array}{l}\text { Croton macrostachyus } \\
\text { Hochst. ex Delile } \\
\text { Euphorbiaceae }\end{array}$} & \multirow[t]{5}{*}{ Mekanissa $(0)$} & \multirow[t]{5}{*}{$\mathrm{T}$} & Malaria & $\begin{array}{l}\text { Fresh or dried leaves are crushed and mixed } \\
\text { with water and drunk. }\end{array}$ \\
\hline & & & Diarrhea & $\begin{array}{l}\text { Shade-dried leaves are powdered, mixed } \\
\text { with hot water, and the mixture taken orally. }\end{array}$ \\
\hline & & & Chiffea & $\begin{array}{l}\text { Crushed fresh leaves with honey are used as } \\
\text { ointment. }\end{array}$ \\
\hline & & & Wound & $\begin{array}{l}\text { Juice of fresh leaves is mixed with coconut } \\
\text { milk and applied topically on skin. }\end{array}$ \\
\hline & & & Black leg & Powder is mixed with attela and drunk. \\
\hline
\end{tabular}




\begin{tabular}{|c|c|c|c|c|}
\hline Scientific name & Local name & Habit & Uses & Mode of Preparation \\
\hline $\begin{array}{l}\text { Cynoglossum amplifolium } \\
\text { Hochst. ex A.DC. } \\
\text { Boraginaceae } \\
\end{array}$ & Kerchaba $(\mathrm{O})$ & $\mathrm{H}$ & Mich & Fresh leaves are chewed. \\
\hline $\begin{array}{l}\text { Datura stramonium L. } \\
\text { Solanaceae }\end{array}$ & Astefaris $(A)$ & $\mathrm{H}$ & Skin wounds & $\begin{array}{l}\text { Paste of the whole plant is used as an insect } \\
\text { repellent and for treatment of wounds and } \\
\text { itches. }\end{array}$ \\
\hline \multirow{3}{*}{$\begin{array}{l}\text { Dodonaea } \\
\text { angustifolia L.f. } \\
\text { Sapindaceae }\end{array}$} & \multirow[t]{3}{*}{ Itach $(0)$} & \multirow[t]{3}{*}{$S$} & Skin wounds & $\begin{array}{l}\text { Powdered leaf is mixed with honey and } \\
\text { applied as paste. }\end{array}$ \\
\hline & & & Thyroid & $\begin{array}{l}\text { Roots are boiled in water and drunk for } 3 \\
\text { days. }\end{array}$ \\
\hline & & & Snake bite & $\begin{array}{l}\text { Young leaf buds are ground into a paste, } \\
\text { mixed with hot water, and administered orally. }\end{array}$ \\
\hline $\begin{array}{l}\text { Echinops kebericho } \\
\text { Mesfin } \\
\text { Asteraceae } \\
\end{array}$ & Kebericho $(A)$ & $\mathrm{H}$ & $\begin{array}{l}\text { Cough, } \\
\text { headache }\end{array}$ & Bulbs are infused, inhaled, and smoked. \\
\hline \multirow{2}{*}{$\begin{array}{l}\text { Ensete ventricosum } \\
\text { (Welw.) Cheesman } \\
\text { Musaceae }\end{array}$} & \multirow[t]{2}{*}{ Utae } & \multirow[t]{2}{*}{$\mathrm{s}$} & $\begin{array}{l}\text { Amoebic } \\
\text { dysentery }\end{array}$ & $\begin{array}{l}\text { Prepared food from Ensete is eaten with } \\
\text { butter and meat. }\end{array}$ \\
\hline & & & Chiffea & $\begin{array}{l}\text { Leaf infusion is used to paste on edge of the } \\
\text { body part where chiffea is found. }\end{array}$ \\
\hline \multirow{2}{*}{$\begin{array}{l}\text { Euphorbia abyssinica } \\
\text { J.F.Gmel. } \\
\text { Euphorbiaceae }\end{array}$} & \multirow[t]{2}{*}{ Qulqwal (A) } & \multirow[t]{2}{*}{$\mathrm{T}$} & Hemorrhoid & $\begin{array}{l}\text { Crushed leaves mixed with water are used } \\
\text { as a rubbing and dressing. }\end{array}$ \\
\hline & & & Skin wounds & $\begin{array}{l}\text { Paste of exudates is applied to edge of } \\
\text { wounds. }\end{array}$ \\
\hline $\begin{array}{l}\text { Euphorbia crotonoides } \\
\text { Boiss. } \\
\text { Euphorbiaceae }\end{array}$ & Anno & $\mathrm{H}$ & Skin wounds & $\begin{array}{l}\text { Paste of exudates is applied to edge of } \\
\text { wounds. }\end{array}$ \\
\hline \multirow{2}{*}{$\begin{array}{l}\text { Euphorbia tirucalli L. } \\
\text { Euphorbiaceae }\end{array}$} & \multirow[t]{2}{*}{ Kinichibae $(A)$} & \multirow[t]{2}{*}{$S$} & Evil eye & Young branches are burnt for smoke bath. \\
\hline & & & Epilepsy & Boiled roots mixed with sugar are drunk. \\
\hline \multirow{2}{*}{$\begin{array}{l}\text { Euphorbia schizacantha } \\
\text { Pax } \\
\text { Euphorbiaceae }\end{array}$} & \multirow[t]{2}{*}{ Dhetungayda } & \multirow[t]{2}{*}{$\mathrm{H}$} & Cough & $\begin{array}{l}\text { Pounded leaves are mixed with butter and } \\
\text { drunk. }\end{array}$ \\
\hline & & & Internal worms & Roots are chewed. \\
\hline \multirow{3}{*}{$\begin{array}{l}\text { Grewia villosa Willd. } \\
\text { Malvaceae }\end{array}$} & \multirow[t]{3}{*}{ Bururi } & \multirow[t]{3}{*}{$S$} & Snake bite & Roots are chewed. \\
\hline & & & Diarrhea & Juice of leaves is taken orally. \\
\hline & & & Gonorrhea & $\begin{array}{l}\text { Dried and powdered leaves are mixed with } \\
\text { melted butter and drunk. }\end{array}$ \\
\hline $\begin{array}{l}\text { Gymnosporia } \\
\text { senegalensis } \\
\text { (Lam.) Loes. } \\
\text { Celastraceae } \\
\end{array}$ & $\begin{array}{l}\text { Kombolcha } \\
\text { (O) }\end{array}$ & $S$ & Evil eye & $\begin{array}{l}\text { Leaf, bark, and root are dried, powdered, and } \\
\text { mixed together with honey and drunk as tea } \\
\text { thrice daily morning for } 3 \text { days. }\end{array}$ \\
\hline \multirow[t]{3}{*}{$\begin{array}{l}\text { Indigofera spicata Forssk. } \\
\text { Fabaceae }\end{array}$} & \multirow[t]{3}{*}{ Korsita } & \multirow[t]{3}{*}{$\mathrm{H}$} & Snake bite & $\begin{array}{l}\text { Crushed fresh leaf and stem are added to } \\
\text { bath. }\end{array}$ \\
\hline & & & Scabies & \multirow{2}{*}{$\begin{array}{l}\text { Leaf is powdered, mixed with butter, and } \\
\text { massaged on the scabies and chiffea. }\end{array}$} \\
\hline & & & Chiffea & \\
\hline \multirow{3}{*}{$\begin{array}{l}\text { Ipomoea kituiensis var. } \\
\text { massaiensis Verdc. } \\
\text { Convolvulaceae }\end{array}$} & \multirow[t]{3}{*}{ Laalata } & \multirow[t]{3}{*}{$\mathrm{C}$} & Malaria & Juice of fresh leaves is drunk with coffee. \\
\hline & & & Yeferes ekeke & $\begin{array}{l}\text { Root is powdered, mixed with butter, and } \\
\text { rubbed on the swelling. }\end{array}$ \\
\hline & & & Anthrax & $\begin{array}{l}\text { Root is crushed and mixed with water or } \\
\text { attela. }\end{array}$ \\
\hline
\end{tabular}


Mesfin et al. - An Ethnobotanical Study of Medicinal Plants in Amaro Woreda, 347 Ethiopia

\begin{tabular}{|c|c|c|c|c|}
\hline Scientific name & Local name & Habit & Uses & Mode of Preparation \\
\hline \multirow[t]{3}{*}{$\begin{array}{l}\text { Lepidium sativum } \mathrm{L} \text {. } \\
\text { Brassicaceae }\end{array}$} & \multirow[t]{3}{*}{ Fexxo $(A)$} & \multirow[t]{3}{*}{$\mathrm{H}$} & Mich & $\begin{array}{l}\text { Powdered leaf mixed with water or coffee is } \\
\text { taken orally. }\end{array}$ \\
\hline & & & Malaria & $\begin{array}{l}\text { Dried fruit is ground into powder, mixed with } \\
\text { castor oil, and administered orally. }\end{array}$ \\
\hline & & & Cough & A tea is made from leaves. \\
\hline \multirow{2}{*}{$\begin{array}{l}\text { Maesa lanceolata Forssk. } \\
\text { Primulaceae }\end{array}$} & \multirow[t]{2}{*}{ Abayi (A) } & \multirow[t]{2}{*}{$\mathrm{T}$} & \multirow[t]{2}{*}{ Snake bite } & Powdered leaf is mixed with butter and drunk. \\
\hline & & & & Chewing fresh leaves. \\
\hline \multirow{2}{*}{$\begin{array}{l}\text { Nicandra physalodes } \\
\text { (L.) Gaertn. } \\
\text { Solanaceae }\end{array}$} & \multirow[t]{2}{*}{ Machara } & \multirow[t]{2}{*}{ C } & Leishmania & Powdered leaf is mixed with water and drunk. \\
\hline & & & Yeferes ekeke & $\begin{array}{l}\text { Powdered leaf is mixed with water and used } \\
\text { as paste. }\end{array}$ \\
\hline \multirow[t]{3}{*}{$\begin{array}{l}\text { Nicotiana tabacum L. } \\
\text { Solanaceae }\end{array}$} & \multirow[t]{3}{*}{ Tombowae } & \multirow[t]{3}{*}{$\mathrm{H}$} & Hemorrhoid & $\begin{array}{l}\text { Oil extracted from fresh leaves is squeezed } \\
\text { on edge. }\end{array}$ \\
\hline & & & Diarrhea & $\begin{array}{l}\text { Crushed, decocted, and concocted fresh } \\
\text { leaves are taken, and powdered roots are } \\
\text { mixed with water or milk and drunk. }\end{array}$ \\
\hline & & & Gonorrhea & $\begin{array}{l}\text { The mixture above is taken orally along with } \\
\text { hot water. }\end{array}$ \\
\hline \multirow{2}{*}{$\begin{array}{l}\text { Ocimum lamiifolium } \\
\text { Hochst. ex Benth. } \\
\text { Lamiaceae }\end{array}$} & \multirow[t]{2}{*}{ Damakasie $(A)$} & \multirow[t]{2}{*}{$\mathrm{H}$} & Mich & $\begin{array}{l}\text { Fresh leaf juice is mixed with coffee and } \\
\text { drunk. }\end{array}$ \\
\hline & & & Evil eye & $\begin{array}{l}\text { Crushed leaves are squeezed or smoke } \\
\text { inhaled. }\end{array}$ \\
\hline \multirow{3}{*}{$\begin{array}{l}\text { Olea europaea subsp. } \\
\text { cuspidata (Wall. \& G.Don) } \\
\text { Cif. } \\
\text { Oleaceae }\end{array}$} & \multirow[t]{3}{*}{ Ejersa $(O)$} & \multirow[t]{3}{*}{$\mathrm{T}$} & Hemorrhoid & Extracted oil from boiled stem is taken orally. \\
\hline & & & Skin wound & Decoctions of leaves are applied as paste. \\
\hline & & & Scabies & $\begin{array}{l}\text { Powdered roots are mixed with butter and } \\
\text { applied as paste. }\end{array}$ \\
\hline \multirow[t]{2}{*}{$\begin{array}{l}\text { Rhamnus prinoides L'Her. } \\
\text { Rhamnaceae }\end{array}$} & \multirow[t]{2}{*}{ Gesho (A) } & \multirow[t]{2}{*}{$\mathrm{s}$} & Chiffea & $\begin{array}{l}\text { Crushed fresh leaves are mixed with butter } \\
\text { and applied as ointment. }\end{array}$ \\
\hline & & & Snake bite & $\begin{array}{l}\text { Leaves are mixed with lemon juice and are } \\
\text { directly applied as paste on the wound. }\end{array}$ \\
\hline \multirow{2}{*}{$\begin{array}{l}\text { Rhus natalensis Bernh. } \\
\text { ex C.Krauss } \\
\text { Anacardiaceae }\end{array}$} & \multirow[t]{2}{*}{ unknown } & \multirow[t]{2}{*}{$\mathrm{S}$} & Malaria & $\begin{array}{l}\text { Decocted fresh leaves are drunk at morning } \\
\text { for } 3 \text { days. }\end{array}$ \\
\hline & & & Cough & $\begin{array}{l}\text { Decocted fresh leaves are drunk or used for } \\
\text { bathing for } 3 \text { days to relieve fever in children. }\end{array}$ \\
\hline \multirow{4}{*}{$\begin{array}{l}\text { Rumex nepalensis } \\
\text { Spreng. } \\
\text { Polygonaceae }\end{array}$} & \multirow[t]{4}{*}{ Tullet $(A)$} & \multirow[t]{4}{*}{$\mathrm{H}$} & Quaquchia & Fresh leaves used as a rub. \\
\hline & & & Hemorrhoid & Powder is squeezed on cut edge. \\
\hline & & & Hypertension & Fresh leaves are boiled and drunk. \\
\hline & & & $\begin{array}{l}\text { Amoebic } \\
\text { dysentery }\end{array}$ & $\begin{array}{l}\text { Leaf and root powder is mixed with honey } \\
\text { and taken. }\end{array}$ \\
\hline \multirow{4}{*}{$\begin{array}{l}\text { Ruta chalepensis L. } \\
\text { Rutaceae }\end{array}$} & \multirow[t]{4}{*}{ Xenadame $(\mathrm{A})$} & \multirow[t]{4}{*}{$\mathrm{H}$} & Stomach ache & Fresh leaves are chewed. \\
\hline & & & Mich & Fresh leaves or seeds are chewed. \\
\hline & & & Malaria & $\begin{array}{l}\text { Leaf powder is mixed with water and drunk } \\
\text { in the morning before breakfast for } 3 \text { days. }\end{array}$ \\
\hline & & & Evil eye & $\begin{array}{l}\text { Fresh leaves are mixed with coffee and } \\
\text { drunk. }\end{array}$ \\
\hline
\end{tabular}




\begin{tabular}{|c|c|c|c|c|}
\hline Scientific name & Local name & Habit & Uses & Mode of Preparation \\
\hline \multirow{2}{*}{$\begin{array}{l}\text { Salvia nilotica Juss. } \\
\text { ex Jacq. } \\
\text { Lamiaceae }\end{array}$} & \multirow[t]{2}{*}{ Shokoksa $(0)$} & \multirow[t]{2}{*}{$\mathrm{H}$} & Hemorrhoids & $\begin{array}{l}\text { Milky heated leaves are dressed on body } \\
\text { part where hemorrhoids are found. }\end{array}$ \\
\hline & & & Diarrhea & The fruit juice is taken orally. \\
\hline \multirow{6}{*}{$\begin{array}{l}\text { Sida schimperiana } \\
\text { Hochst. ex A.Rich. } \\
\text { Malvaceae }\end{array}$} & \multirow{6}{*}{$\begin{array}{l}\text { Locally no } \\
\text { consistent } \\
\text { name. }\end{array}$} & \multirow[t]{6}{*}{$S$} & $\begin{array}{l}\text { Prenatal } \\
\text { abortion }\end{array}$ & Fruit are tied around forehead. \\
\hline & & & Internal worms & $\begin{array}{l}\text { Dried root and leaf powder are mixed with } \\
\text { water and drunk before breakfast for } 3 \text { days. }\end{array}$ \\
\hline & & & $\begin{array}{l}\text { Amoebic } \\
\text { dysentery }\end{array}$ & $\begin{array}{l}\text { Powder is mixed with melted butter and } \\
\text { drunk. }\end{array}$ \\
\hline & & & Cough & $\begin{array}{l}\text { Fresh leaves are crushed and drunk with } \\
\text { honey. }\end{array}$ \\
\hline & & & Influenza & $\begin{array}{l}\text { Leaf juice is used against cough and } \\
\text { influenza. }\end{array}$ \\
\hline & & & Liver disease & $\begin{array}{l}\text { Root juice is mixed with milk and drunk for } \\
5 \text { days. }\end{array}$ \\
\hline \multirow[t]{5}{*}{$\begin{array}{l}\text { Solanum incanum } \mathrm{L} . \\
\text { Solanaceae }\end{array}$} & \multirow[t]{5}{*}{ Embuay } & \multirow[t]{5}{*}{$S$} & Gonorrhea & $\begin{array}{l}\text { Dried root powder mixed with water and } \\
\text { sugar is drunk. }\end{array}$ \\
\hline & & & Hemorrhoid & $\begin{array}{l}\text { Dried leaf powder is mixed with honey and } \\
\text { paste is applied on edge. }\end{array}$ \\
\hline & & & Rabies & $\begin{array}{l}\text { Crushed fresh leaf is mixed with water and } \\
\text { drunk for } 3 \text { days. }\end{array}$ \\
\hline & & & Contraceptive & Fresh leaf mixed with atella and salt is drunk. \\
\hline & & & $\begin{array}{l}\text { Prenatal } \\
\text { abortion }\end{array}$ & $\begin{array}{l}\text { Juice from stem is used to stop accidental } \\
\text { post-abortion bleeding in cows. }\end{array}$ \\
\hline \multirow{5}{*}{$\begin{array}{l}\text { Syzygium guineense } \\
\text { (Willd.) DC. } \\
\text { Myrtaceae }\end{array}$} & \multirow[t]{5}{*}{ Duwancho } & \multirow[t]{5}{*}{$\mathrm{T}$} & Malaria & $\begin{array}{l}\text { Well powdered leaves are taken with cold } \\
\text { tea. }\end{array}$ \\
\hline & & & Hemorrhoid & $\begin{array}{l}\text { Paste of whole plant is applied to stop } \\
\text { bleeding. }\end{array}$ \\
\hline & & & Internal worms & Decoction is taken internally. \\
\hline & & & Snake bite & Powdered root mixed with water is taken. \\
\hline & & & Gonorrhea & Juice from stem is taken for sexual diseases. \\
\hline \multirow[t]{2}{*}{$\begin{array}{l}\text { Terminalia brownii } \\
\text { Fresen. } \\
\text { Combretaceae }\end{array}$} & \multirow[t]{2}{*}{ Olpata } & \multirow[t]{2}{*}{$\mathrm{T}$} & Anthrax & $\begin{array}{l}\text { Leaves along with root and bark of } N \text {. } \\
\text { tabacum are used to prepare a soup and } \\
\text { administered internally. }\end{array}$ \\
\hline & & & Skin wounds & $\begin{array}{l}\text { Leaf is dried, powdered, applied on wound, } \\
\text { and tied up by its stem bark. }\end{array}$ \\
\hline \multirow[t]{2}{*}{$\begin{array}{l}\text { Vepris glomerata Engl. } \\
\text { Rutaceae }\end{array}$} & \multirow[t]{2}{*}{ unknown } & \multirow[t]{2}{*}{$S$} & Snake bite & $\begin{array}{l}\text { Roots and leaves are mixed with leaves of } M \text {. } \\
\text { lanceolata, ground together, and taken with } \\
\text { cold tea. }\end{array}$ \\
\hline & & & Skin disease & Leaf is crushed and placed over the skin. \\
\hline \multirow{3}{*}{$\begin{array}{l}\text { Verbena officinalis L. } \\
\text { Verbenaceae }\end{array}$} & \multirow[t]{3}{*}{ Dargu $(A)$} & \multirow[t]{3}{*}{$\mathrm{H}$} & Stomach ache & Root is chewed. \\
\hline & & & $\begin{array}{l}\text { Amoebic } \\
\text { dysentery }\end{array}$ & Powder mixed with water is drunk. \\
\hline & & & Gonorrhea & Root is chewed. \\
\hline
\end{tabular}


Mesfin et al. - An Ethnobotanical Study of Medicinal Plants in Amaro Woreda, 349 Ethiopia

\begin{tabular}{|c|c|c|c|c|}
\hline Scientific name & Local name & Habit & Uses & Mode of Preparation \\
\hline \multirow{4}{*}{$\begin{array}{l}\text { Vernonia amygdalina } \\
\text { Delile } \\
\text { Asteraceae }\end{array}$} & \multirow[t]{4}{*}{ Birmayda } & \multirow[t]{4}{*}{$S$} & Internal worms & $\begin{array}{l}\text { Fresh leaves crushed and mixed with honey } \\
\text { are taken. }\end{array}$ \\
\hline & & & Stomach ache & Root is chewed. \\
\hline & & & Malaria & $\begin{array}{l}\text { Leaves and bark mixed with honey is taken } \\
\text { for days in morning and evening. }\end{array}$ \\
\hline & & & Mich & $\begin{array}{l}\text { Shoot tips are collected and crushed, mixed } \\
\text { with water, and drunk. Tella is the antidote } \\
\text { against the vomiting that immediately follows. }\end{array}$ \\
\hline \multirow{3}{*}{$\begin{array}{l}\text { Withania somnifera (L.) } \\
\text { Dunal } \\
\text { Solanaceae }\end{array}$} & \multirow[t]{3}{*}{ Chomatita } & \multirow[t]{3}{*}{$\mathrm{H}$} & Mich & Smoke made from root is inhaled. \\
\hline & & & Evil eye & Smoke made from root is inhaled. \\
\hline & & & Yeferes ekeke & Used for washing the body of the animal. \\
\hline \multirow{3}{*}{$\begin{array}{l}\text { Zingiber officinale Roscoe } \\
\text { Zingiberaceae }\end{array}$} & \multirow[t]{3}{*}{ Jinjibelloae } & \multirow[t]{3}{*}{$\mathrm{H}$} & Stomach ache & Rhizome is chewed. \\
\hline & & & Internal worms & Leaf decoction is taken internally to get relief. \\
\hline & & & $\begin{array}{l}\text { Male sexual } \\
\text { impotence }\end{array}$ & $\begin{array}{l}\text { Rhizomes are chewed, swallowing the } \\
\text { exudates. }\end{array}$ \\
\hline
\end{tabular}

\& Giday 2007)), gonorrhea, and abdominal dysentery (5 plants each); and stomach ache, headache, skin diseases, and evil eye (a look that is believed by the local people to be able to cause a fever or headache) (4 plants each). Only three plants each were used to treat diarrhea, chiffea (eczema), and burning and two each for hypertension, scabies, influenza, sexual impotency, and tooth ache. Some plants were used in the treatment of more than one disease. For example, different parts (leaves, stem bark, latex, and root bark) of Sida schimperiana Hochst. ex A.Rich. were used to treat six diseases. Croton macrostachyus Hochst. ex Delile, Solanum incanum L., and Syzygium guineense (Willd.) DC. each were used for treatment of five diseases.

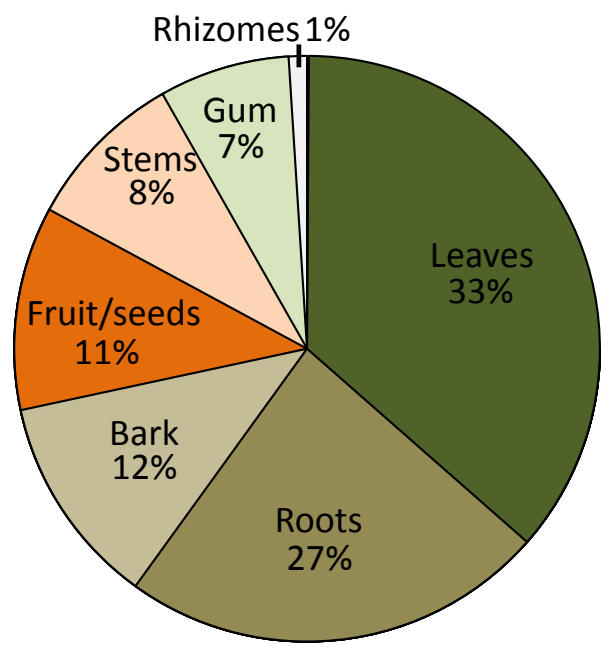

Figure 3. Plant parts used by Korre ethnic group, Amaro Woreda, SNNPR, Ethiopia. Gum includes other exudates.
Various plant parts were used to prepare remedies (Figure 3). Most remedies prepared were used immediately after harvest; $76 \%$ were processed while fresh and $11 \%$ were prepared after a quick drying. Methods of remedy preparation are reported in Figure 4.

\section{Route of administration and dosage}

Routes of administration are reported in Figure 5. For the treatment of snake bite, $51 \%$ of remedies were applied orally in the form of an infusion or decoction, 34\% were applied topically on the snake bite area, and the rest applied in both forms. Most of the treatments were reported to be completed within two or three days. A majority of drugs were recommended for thrice daily consumption or

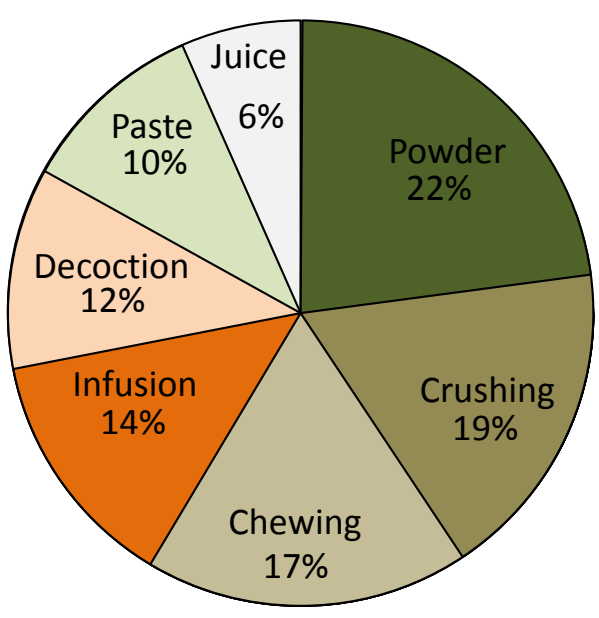

Figure 4. Methods of medicinal plant preparation used by Korre ethnic group, Amaro Woreda, SNNPR, Ethiopia. Crushing includes pounding. 


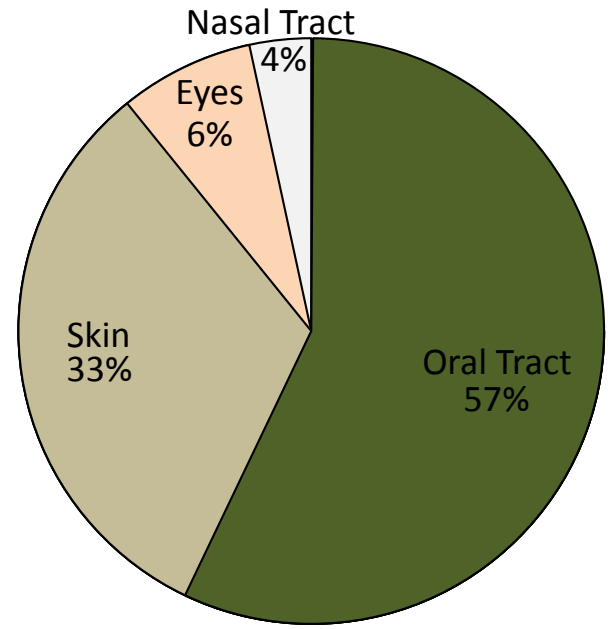

Figure 5. Route of administration of phytomedicines used by Korre ethnic group, Amaro Woreda, SNNPR, Ethiopia.

application. In the case of snake bite treatment, however, the healers kept the patients for two or three days under continuous observation until the patients were recovered. Liquid remedies administrated to patients were usually measured by tea or coffee glasses, spoon or cup, or number of drops. When patients did not show any sign of recovery from their illnesses after completion of a treatment, they turned to nearby modern health centers.

\section{Fidelity level of medicinal plants}

The medicinal plants that are widely used by the local people have higher FL values than those that are less popular. On the other hand, medicinal plants that are known as remedies of a single ailment have $100 \%$ fidelity level as compared to those that are used as remedies for more than one type of aliment. For example, Ruta chalepensis
$\mathrm{L}$. is used to treat stomach ache, mich, malaria, and evil eye, and its $\mathrm{FL}$ value is $45 \%$ which is the lowest. Albuca abyssinica, Carissa spinarum L., Combretum molle R.Br. ex G.Don, and Datura stramonium L., on the other hand, scored the highest possible value of $100 \%$ as they are all used to treat a single ailment (Table 2).

\section{Acquisition and transfer of indigenous knowledge of traditional medicine}

Elder people ( $>50$ years) had better awareness and utilized more varieties of medicinal plants compared to the younger generation. Women of this community have very little knowledge of medicinal plants. Similarly, literate persons of the area were found to have less knowledge of medicinal plants compared to illiterate ones, presumably due to lack of interest. It was also noted that a majority people of this community were hesitant in disclosing their knowledge on medicinal value of the plants. They fear that their societal recognition and reputation, which they have earned due to their knowledge, will be lost and hence they want to keep it secret. The traditional knowledge acquired from their ancestors is freely transferred within the family, preferably to the eldest son, and that's why the male generation of this community has a rich traditional knowledge of medicinal plants. Transfer of this knowledge to the outside world was deemed acceptable only on the basis of substantial payment. Reputed healers of this community do not keep records, and the information is mainly passed on verbally from generation to generation.

\section{Marketability and abundance of medicinal plants}

Most medicinal plants of Korre ethnic group were not available for sale at local markets. Only Allium sativum L., Capsicum annuum L., Catha edulis (Vahl) Endl., Cit-

Table 2. Fidelity level of medicinal plants used by local people of Amaro Woreda, SNNPR, Ethiopia.

\begin{tabular}{|l|l|r|}
\hline Species & Therapeutic use & FL (\%) \\
\hline Albuca abyssinica Jacq. & Snake bite & $100 \%$ \\
\hline Carissa spinarum L. & Gonorrhea & $100 \%$ \\
\hline Combretum molle R.Br. ex G.Don & Malaria & $100 \%$ \\
\hline Datura stramonium L. & Skin wounds & $100 \%$ \\
\hline Allium sativum L. & Influenza, chest pain, malaria & $85 \%$ \\
\hline Artemisia afra Jack. ex Wild & Mich & $85 \%$ \\
\hline Croton macrostachyus Hochst. ex Delile & Malaria, diarrhea, black leg & $85 \%$ \\
\hline Euphorbia crotonoides Boiss & Skin wounds & $67.5 \%$ \\
\hline Lepidium sativum L. & Mich, cough & $67.5 \%$ \\
\hline Ocimum lamiifolium Hochst. ex Benth. & Mich, evil eye & $53.5 \%$ \\
\hline Olea europaea subsp. cuspidata (Wall. \& G.Don) Cif. & Hemorrhoid, skin wounds, scabies & $53.5 \%$ \\
\hline Ruta chalepensis L. & Stomach ache, mich, malaria, evil eye & $45 \%$ \\
\hline
\end{tabular}




\section{Mesfin et al. - An Ethnobotanical Study of Medicinal Plants in Amaro Woreda, 351 Ethiopia}

rus aurantiifolia (Christm.) Swingle, Ensete ventricosum (Welw.) Cheesman, Lepidium sativum L., Nicotiana tabacum L., Ocimum lamiifolium Hochst. ex Benth., Rhamnus prinoides L'Her., $R$. chalepansis, and Zingiber officinale Roscoe were reported to be sold at local markets, but mainly for their uses as spice or food rather than for medicinal purposes. Medicinal plants were freely harvested by users from the immediate environment in which they were abundantly found.

About $(76.8 \%)$ of medicinal plants of Korre ethnic groups were uncultivated species, most of them abundantly growing in disturbed habitats, mainly in crop fields, fallow lands, and along hedgerows. Eleven species were reported to be planted by users in home-gardens and cultivated fields, of which only two (L. sativum and O. lamiifolium) were grown for their sole medicinal values. The other nine were grown primarily for other purposes (spice and food). The abundance of one medicinal plant (Olea europaea subsp. cuspidata (Wall. \& G.Don) Cif.) used by Korre ethnic group was, however, reported to be rapidly declining from time to time, due to selective cutting and/or deforestation for house construction and firewood. Its wood is also frequently used in the area to make charcoal.

\section{Threats to medicinal plants and conservation practices}

The numbers of medicinal plant species threatened in the study area are listed in Table 3. The major factors claimed as threats were, in order, deforestation followed by agricultural expansion, fire, charcoal trading and firewood collection, overgrazing, and drought. The effort to conserve medicinal plants in the community was observed to be very poor. Some traditional practitioners have started to conserve medicinal plants by cultivating homegardens, though the effort was minimal. About $23.2 \%$, of the medicinal plants collected were reported as cultivated. Traditional beliefs in the area also have their own unintentional role in conservation and sustainable utilization of medicinal plants.

\section{Discussion}

\section{Diversity of medicinal plant species}

The result of the study is comparable with that of studies conducted on ethnomedicinal plant knowledge and practice of the Oromo ethnic group in southwestern Ethiopia by Yineger et al. (2008). They recorded a total of 67 species of medicinal plants within 65 genera and 35 families. Moreover, the diversity of medicinal plant species is also comparable to Gedeo people, an ethnic group in southern Ethiopia who use 65 species (Mesfin et al. 2009). The majority $(76 \%)$ of these medicinal plant species were wild, while $13 \%$ were both wild and cultivated and $12 \%$ were only cultivated. Studies elsewhere also reported similar results (Mesfin et al. 2009, Yineger \& Yewhalaw 2007). Other studies recorded even higher number of species used among some of the major ethnic groups in the country, as in the case of Oromo people (the major ethnic group in Ethiopia) residing in Mana Angetu district, southeastern Ethiopia, who make use of 230 species (Lulekal et al. 2008) and the Konta people in southern Ethiopia who make use of about 120 species (Bekalo et al. 2009). On the other hand, the Zay people use relatively fewer species (33) (Giday 2001), which points to the fact that the loss of tradition (cultural shift) in minorities is greater than in larger groups (Luseba \& Van der Merwe 2006).

\section{Ailments treated, plant parts used, and modes of remedy preparations}

As in other parts of the country (Giday 2001, Hunde et al. 2006, Teklehaymanot \& Giday 2007), C. macrostachyus, $S$. incanum, and $S$. guineense each were used for treatment of five diseases. These similarities indicate the wide use of medicinal plant species and the existence of associated knowledge shared among ethnic groups in Ethiopia. The fact that some of the reported plants are having similar uses elsewhere in the world supports their likely pharmacological effectiveness having been tested in different areas by different cultures (Bekalo et al. 2009). It was found from this study that similar medicinal plant species were used by the healers of this community as used by the healers in different parts of Ethiopia.

Table 3. Threat factors of medicinal plants reported by local people of Amaro Woreda, SNNPR, Ethiopia.

\begin{tabular}{|l|c|c|c|c|c|c|c|c|}
\hline \multirow{2}{*}{ Factors } & \multicolumn{9}{|c|}{ Respondents } & \multirow{2}{*}{ Total } & \multirow{2}{*}{ Rank } \\
\cline { 2 - 9 } & R1 & R2 & R3 & R4 & R5 & R6 & & \\
\hline Deforestation & 6 & 2 & 6 & 6 & 5 & 6 & 31 & $1^{\text {th }}$ \\
\hline Agricultural expansion & 4 & 6 & 5 & 4 & 1 & 4 & 24 & $2^{\text {nd }}$ \\
\hline Fire & 5 & 1 & 3 & 5 & 4 & 5 & 23 & $3^{\text {rd }}$ \\
\hline Charcoal \& firewood & 3 & 4 & 2 & 3 & 6 & 3 & 21 & $4^{\text {th }}$ \\
\hline Overgrazing & 2 & 5 & 4 & 1 & 2 & 1 & 15 & $5^{\text {th }}$ \\
\hline Drought & 1 & 3 & 1 & 2 & 3 & 2 & 12 & $6^{\text {th }}$ \\
\hline
\end{tabular}


The diversity of plant parts found by this study agrees with the results obtained from other ethnomedicinal studies; Lulekal et al. (2008), Mesfin et al. (2009), Yineger et al. (2008), and Awas and Demissew (2009) all reported that leaves were the plant parts most used in medicine preparations. The preference of leaves to other plant parts could be due to (1) ease of collection and preparation, (2) preparation of medicinal teas (Gazzaneo et al. 2005), and/or (3) the presence of more bioactive ingredients in leaves developed in response to phytophagous organisms since leaves are the most vulnerable parts of a plant (Bhattarai et al. 2006).

Lulekal et al. (2008) and Yineger et al. (2008) also found that most prepared remedies were used immediately after harvest. Thirty-seven percent of the Korre remedies were reported to be dried and stored for future use. The frequent use of freshly processed remedies could indicate copious availability of plant materials in the vicinity that could be picked up at any time. Other studies conducted elsewhere also indicated the wider use of fresh materials (Yineger et al. 2008). The frequent use of fresh materials might also be an attempt not to lose volatile oils, the concentration of which could deteriorate on drying

\section{Acquisition and transfer of indigenous knowledge of traditional medicine}

The secrecy of traditional medical practice is also a common phenomenon found in other parts of Ethiopia and worldwide (Yineger \& Yewhalaw 2007). Knowledge is dwindling rapidly due to changes towards western culture, modern agricultural practices, other cultural changes within the community, rapid shift towards the allopathic medicine, and establishing of housing colonies. Modern education leads to destruction of not only the habitats of medicinal plants, but also resulted in vanishing of traditional knowledge in the area. Similarly, the threat to traditional knowledge was also observed in other parts of Ethiopia due to less interest by the younger generation (Lulekal et al. 2008, Mesfin et al. 2009).

\section{Marketability and abundance of medicinal plants}

In contrast to the lack of market avaiability of medicinal plants amoung the Korre ethnic group, other studies conducted elsewhere in Ethiopia have indicated a wide domestic trade of medicinal plants (Balemie et al. 2004, Teklehaymanot \& Giday 2007). In contrast to some developing countries, there is no official report, so far, of any medicinal plant exports from the country.

Observed abundance of medicinal plants might increase in the future due to agricultural expansion and rising private investment in the area. A study conducted in the rural Bahir Dar Zuria district, northwestern Ethiopia (Teklehaymanot \& Giday 2007), also showed the common use of weeds for medicinal purposes. Similarly, a study carried out in Pernambuco State, Brazil (Gazzaneo et al. 2005), indicated the frequent use by herbalists of weeds harvested from back yards and small farms. It was stated that weeds are often abundant near at hand, easy to harvest, and are frequently rich in bioactive compounds and as a result they are amply represented in contemporary tropical healing floras (Abebe \& Hagos 1991).

\section{Threats to medicinal plants and conservation practices}

Other research on threats to medicinal plants used by Kereyu pastoralists in Ethiopia (Balemie et al. 2004) indicates similar results.

\section{Conclusions and Recommendations}

The use of medicinal plants is playing an important role in meeting the primary healthcare needs of the Korre ethnic group in Amaro Woreda. Acceptance of traditional medicine and limited access to modern healthcare facilities could be considered as the main factors for the continuation of the practices. The majority of medicinal plants used by this ethnic group were herbs which could be attributed to herb abundance in areas very close to houses as compared to relative infrequency of trees or shrubs. Newly harvested plant materials are mostly used in the preparation of remedies, which is an indication of the availability of copious plant materials in the vicinity to be picked any time, rather than storing the material. The plants Albuca abyssinica (for snake bite), Carissa spinarum (for gonorrhea), Combretum molle (for malaria), and Datura stramonium (for skin wounds) had the highest FL values, an indication of their high healing potential. Priority should, therefore, be given to these plants to test their efficacy and toxicity. As there is no adequate modern healthcare provision in the study area, so loss of traditional knowledge and practice could negatively affect the healthcare system of the people. In this situation, awareness of the contribution of traditional medical practice towards fulfilling the primary healthcare needs of the local people should be created among the youth. The younger generations have shown less interest of seeking knowledge on traditional ethnobotanical practices. As a result, collecting and compiling indigenous knowledge as written documents would be beneficial for the community. The government and particularly NGOs involved in ethnobotanical studies should play important roles in sponsoring ethnobotanical and ethnopharmaceutical studies to collect, compile, and preserve such crucial indigenous knowledge for posterity before it disappears. Giving conservation priority for identified threatened medicinal plants, promoting in-situ and ex-situ conservation of medicinal plants in Korre community, and supporting the district's Traditional Healers Association-by providing funds, land for cultivating medicinal plants, and assisting their activities with professional guid- 


\section{Mesfin et al. - An Ethnobotanical Study of Medicinal Plants in Amaro Woreda, 353 Ethiopia}

ance-will help to conserve the rapidly dwindling medicinal plants of the study area.

\section{Acknowledgments}

We would like to thank Dilla University, Ethiopia, for financial support so as to carry out this study. Moreover, our appreciation goes to the woreda officers and also the sampled traditional healers of Amaro for giving us valuable information to compile this article.

\section{Literature Cited}

Abebe, D. 2001. The role of medicinal plants in healthcare coverage of Ethiopia, the possible benefits of integration. Pp. 6-21 in Conservation and Sustainable Use of Medicinal Plants in Ethiopia, Proceedings of the National Workshop, 28 April-01 May 1998. Edited by M. Zewdu. Demissie A. Institute of Biodiversity Conservation and Research, Addis Ababa, Ethiopia.

Abebe, D. \& E. Hagos. 1991. Plants as a primary source of drugs in the traditional health practices of Ethiopia. Pp.101-113 in Plant Genetic Resources of Ethiopia. Edited by J.M.M. Engles, J.G. Hawkes \& M. Worede. Cambridge University Press, Cambridge, U.K. dx.doi. org/10.1017/CBO9780511551543.007

Alexiades, M.N. \& J.W. Sheldon. 1996. Editors of Selected Guidelines for Ethnobotanical Research: A field manual. New York Botanical Garden Press, Bronx, New York, U.S.A.

Awas, T. \& S. Demissew. 2009. Ethnobotanical study of medicinal plants in Kafficho people, southwestern Ethiopia. Pp. 711-726 in Proceedings of the 16th International Conference of Ethiopian Studies. Edited by S. Ege, H. Aspen, B. Teferra \& S. Bekele. Department of Social Anthropology, Norwegian University of Science and Technology, Trondheim, Norway.

Balemie, K., E. Kelbessa \& Z. Asfaw. 2004. Indigenous medicinal plant utilization, management and threats in Fentalle area, Eastern Shewa, Ethiopia. Ethiopian Journal of Biological Sciences 3:37-58.

Bekalo, T.H., S.D. Woodmatas \& Z.A. Woldemariam. 2009. An ethnobotanical study of medicinal plants used by local people in the lowlands of Konta Special Woreda, southern nations, nationalities and peoples regional state, Ethiopia. Journal of Ethnobiology and Ethnomedicine 5:26. dx.doi.org/10.1186/1746-4269-5-26

Bekele, E. 2007. Study on Actual Situation of Medicinal Plants in Ethiopia. Prepared for Japan Association for International Collaboration of Agriculture and Forestry, Addis Ababa, Ethiopia.
Belayneh, A., Z. Asfaw, S. Demissew, \& N. Bussa. 2012 Medicinal plants potential and use by pastoral and agropastoral communities in Erer Valley of Babile Wereda, Eastern Ethiopia. Journal of Ethnobiology and Ethnomedicine 8:42. dx.doi.org/10.1186/1746-4269-8-42

Bhattarai, S., R.P. Chaudhary \& R.S.L. Taylor. 2006. Ethnomedicinal plants used by the people of Manang district, central Nepal. Journal of Ethnobiology and Ethnomedicine 2:41. $\mathrm{dx}$.doi.org/10.1186/1746-4269-2-41

CSA (Central Statistical Agency). 2005. National Statistics Abstract: Population. Central Statistical Agency of Ethiopia. www.csa.gov.et

Edwards, S., S. Demissew \& I. Hedberg. 1997. Editors of Flora of Ethiopia and Eritrea. Hydrocharitaceae to Arecaceae. Volume 6. The National Herbarium, Addis Ababa, Ethiopia, and Department of Systematic Botany, Uppsala, Sweden.

Edwards, S., M. Tadesse, S. Demissew \& I. Hedberg. 2000. Editors of Flora of Ethiopia and Eritrea. Magnoliaceae to Flacourtiaceae. Volume 2, Part 1. The National Herbarium, Addis Ababa, Ethiopia, and Department of Systematic Botany, Uppsala, Sweden.

Edwards, S., M. Tadesse \& I. Hedberg. 1995. Editors of Flora of Ethiopia and Eritrea. Canellaceae to Euphorbiaceae, Volume 2, Part 2. The National Herbarium, Addis Ababa, Ethiopia, and Department of Systematic Botany, Uppsala, Sweden.

Gazzaneo, L.R.S., R.F.P. Lucena \& U.P. Albuquerque. 2005. Knowledge and use of medicinal plants by local specialists in an region of Atlantic Forest in the state of Pernambuco (Northeastern Brazil). Journal of Ethnobiology and Ethnomedicine 1:9. dx.doi.org/10.1186/17464269-1-9

Giday, M. 2001. An Ethnobotanical Study on Medicinal Plants used by the Zay People in Ethiopia. M.S. Thesis, Centrum för Biologisk Mångfald, Uppsala, Sweden.

Hedberg, I. \& S. Edwards. 1989. Editors of Flora of Ethiopia and Eritrea. Pittosporaceae to Araliaceae. Volume 3. The National Herbarium, Addis Ababa, Ethiopia, and Department of Systematic Botany, Uppsala, Sweden.

Hedberg I. \& S. Edwards. 1995. Editors of Flora of Ethiopia and Eritrea. Poaceae. Volume 7. The National Herbarium, Addis Ababa, Ethiopia, and Department of Systematic Botany, Uppsala, Sweden.

Hedberg, I., S. Edwards \& S. Nemomissa. 2003. Editors of Flora of Ethiopia and Eritrea. Apiaceae to Dipsacaceae. Volume 4, Part 1. The National Herbarium, Addis Ababa, 
Ethiopia, and Department of Systematic Botany, Uppsala, Sweden.

Hedberg, I., I. Friis \& S. Edwards. 2004. Editors of Flora of Ethiopia and Eritrea. Asteraceae. Volume 4, Part 2. The National Herbarium, Addis Ababa, Ethiopia, and Department of Systematic Botany, Uppsala, Sweden.

Heinrich, M., A. Ankli, B. Frei, C. Weimann \& O. Sticher. 1998. Medicinal plants in Mexico: Healers' consensus and cultural importance. Social Science and Medicine 47:1859-1871. dx.doi.org/10.1016/S02779536(98)00181-6

Hunde, D., Z. Asfaw \& E. Kelbessa. 2006. Use of traditional medicinal plants by people of 'Boosat' sub district, Central Eastern Ethiopia. Ethiopian Journal of Health Sciences 16(2):141-155.

Kibebew, F. 2001. The status and availability of oral and written knowledge on traditional health care on traditional health care in Ethiopia. Pp.107-119 in Conservation and Sustainable use of Medicinal Plants in Ethiopia. Proceedings of the national workshop, 28 April - 01 May 1998. Edited by M. Zewdu, Demissie A. Institute of Biodiversity Conservation and Research, Addis Ababa, Ethiopia.

Lulekal, E., E. Kelbessa, T. Bekele \& H. Yineger. 2008. An ethnobotanical study of medicinal plants in Mana Angetu District, southeastern Ethiopia. Journal of Ethnobiology and Ethnomedicine 4:10. dx.doi.org/10.1186/1746-4269$\underline{4-10}$

Luseba, D. \& D. Van der Merwe. 2006. Ethnoveterinary medicine practices among Tsonga speaking people of South Africa. Onderstepoort Journal of Veterinary Research 73(2):115-122. dx.doi.org/10.4102/ojvr.v73i2.156

Marshall, N.T. 1998. Searching for a Cure: Conservation of medicinal wildlife resources in East and Southern Af- rica. A TRAFFIC Network Report. TRAFFIC International, Cambridge, U.K.

Martin, G.J. 1995. Ethnobotany. A methods manual. People and Plants Conservation Series. Chapman \& Hall, London, U.K.

Mesfin, F., S. Demissew \& T. Teklehaymanot. 2009. An ethnobotanical study of medicinal plants in Wonago Woreda, SNNPR, Ethiopia. Journal of Ethnobiology and Ethnomedicine 5:28 1-18. dx.doi.org/10.1186/1746-4269-5-28

Regassa, R. 2013. Assessment of indigenous knowledge of medicinal plant practice and mode of service delivery in Hawassa city, southern Ethiopia. Journal of Medicinal Plants Research 7(9):517-535.

Teklehaymanot, T. \& M. Giday. 2007. Ethnobotanical study of medicinal plants used by people in Zegie Peninsula, Northwestern Ethiopia. Journal of Ethnobiology and Ethnomedicine 3:12. dx.doi.org/10.1186/1746-4269-3-12

UNEP (United Nations Environment Program). 1995. Global Biodiversity Assessment. United Nations Environment Program, Nairobi, Kenya.

Yineger, H. \& D. Yewhalaw. 2007. Traditional medicinal plant knowledge and use by local healers in Sekoru District, Jimma Zone, Southwestern Ethiopia. Journal of Ethnobiology and Ethnomedicine 3:24. dx.doi. org/10.1186/1746-4269-3-24

Yineger, H., D. Yewhalaw \& D. Teketay. 2008. Ethnomedicinal plant knowledge and practice of the Oromo ethnic group in southwestern Ethiopia. Journal of Ethnobiology and Ethnomedicine 4:11. dx.doi.org/10.1186/1746-4269$\underline{4-11}$

Zerabruk, S. \& G. Yirga. 2012. Traditional knowledge of medicinal plants in Gindeberet district, Western Ethiopia. South African Journal of Botany 78:165-169. 